\title{
Social Media and Civil Society in the Governor's Election of North Sumatera 2018
}

\author{
http://dx.doi.org/10.25008/jkiski.v5i1.282
}

\author{
Dedi Sahputra $^{1 *}$, Indra Muda ${ }^{2}$, Taufik Wal Hidayat ${ }^{3}$, Waridah $^{4}$ \\ ${ }^{1234}$ Faculty of Social and Political Sciences - Universitas Medan Area \\ Jl. Kolam Nomor 1 Medan Estate, Medan 20223 - Indonesia \\ ${ }^{*}$ Corresponding author: dedisahputra@staff.uma.ac.id
}

Submitted: 12 January 2020, Revised: 19 March 2020, Accepted: 14 June 2020

Accredited by Kemristekdikti No. 28/E/KPT/2019

\begin{abstract}
The phenomenon of democratization, civil society and the use of social media in North Sumatra found its momentum in the North Sumatra Gubernatorial Election (Pilkada) 2018. This study uses a qualitative descriptive method by presenting descriptive data about the civil society movement that uses social media in the North Sumatra Gubernatorial Election. The results of the research show that the emergence of functional civil society movement has given different colors to local politics in North Sumatra. The movement that served as a means of channeling the community's aspirations, has become a driving factor for the victory of one of the candidates for North Sumatra governor in 2018. The use of social media as a means of interaction, communication, and information forms a pattern in new social movement.
\end{abstract}

Keywords: Aspiration, civil society, governor's election, political communication, social media

\section{Introduction}

The North Sumatra Gubernatorial Election (Pilkada) 2018 took place in the era of industrial revolution 4.0 which was flooded with the use of social media. The phenomenon of social media began in the new millennium around 2003 starting with the MySpace (Fadillahi, 2019: 2). Social media networks such as facebook and twitter that have just emerged in the $21^{\text {st }}$ century, have changed the ways of people's struggle in a broader dimension in an effort to fulfill rights in the context of public space through new ways that currently make it difficult for any party to block SS (Umar, 2016: 127-128). The phenomenon of the use of social media has become more interesting and scholars have conducted a research on the role of social media in various fields such as sociopolitical life, public policy, economy, social solidarity, disaster, and health (Murwani, 2018; Maryani, 2018; Pulido, 2018; Saraswati, 2018; Suardi, 2016; Susanto, 2017; Madueke, 2017; Lee, 2017; Crosby, 2018; Williams, 2018; Fardouly,
2018). In fact, the web-based social networking has turned into a routine activity for every last individual, people, groups that are seen dependent on this technology consistently (Akram, 2017: 353). The social networking websites have become essential need today (Tariq, 2012: 409), and part of the daily life of teenagers today (Thang, 2016: 158). Student communities described their observations of online posts or content that encouraged them to develop behaviors to prevent adverse emotional responses (Abbas, 2019: 16), even social media refines how female students think, interact, communicate, fall in love, their social lifestyle and many more (Chukwuere, 2017: 9939).

The rise of social media has given rise to a new arena of public space for Indonesia middle class as a whole (Jati, 2016: 34). The substantial scale of internet use by Indonesians has also contributed to changing or developing public participation in citizen journalism activities (Ritonga, 2019: 87). Consumers are no longer 
passive, but they are taking an active part in public and political communication, so organizations need to adopt a culture of inter-relational customers, based on trust and transparency (Coelho, 2017: 156). The rapid increase in the use of social media across the world is changing the role that media plays in the political process (Johansson, 2016:35). The communication of the political messages is now communicated mainly through virtual environment (Cela, 2015: 200).

The Pilkada 2018 is a momentum that has triggered the birth of civil society. In this Pilkada there is an idiological division between the interests and aspirations of Muslims on the one hand, and those of non-Muslims on the other. The patterned civil society movement in the Muslim movement emphasizes Islamic symbols. The North Sumatra Gubernatorial Election was followed by two pairs of candidates, namely Edy Rahmayadi and Musa Rajekshah or Ijeck (known as Eramas) which were initially supported by the coalition of the Greater Indonesia Movement (Gerindra) Party, the Prosperous Justice Party (PKS), the National Mandate Party (PAN), and the People's Conscience Party (Hanura).

Later several parties joined in supporting Eramas, namely the Golkar Party, the National Democratic Party (Nasdem), the Democratic Party (PD) and the two new political parties that will take part in the 2019 General Election, the Crescent Star Party (PBB) and the Indonesian Unity Party (Perindo). Meanwhile, the second pair, namely Djarot Saiful Hidayat and Sihar Sitorus (Djoss) were supported by the Indonesian Democratic Party of Struggle (PDIP) and the United Development Party (PPP). The Eramas pair won the gubernatorial election based on the results of recapitulation of votes from 33 municipalities and districts throughout North Sumatra. The Eramas pair excelled in 17 regions, with 3.297.137 votes, while the Djoss pair received 2.424.960 votes in 16 other regions.

The main feature of civil society is the existence of community organizations (Ormas), including active and independent political parties to balance the role of the state (Harahap, 2015: 210). But in the government regime of Joko Widodo-Jusuf Kalla since 2014, there has been a change in the pattern of the civil society movement which tends to wait and see, keep silent or even become partisan. Ormas seem to lose their critical power and are more likely to become supporters of the power. This condition fosters functional civil society that moves based on understanding of the mind, common interests and shared needs (Sahputra, 2019: 53).
Based on the above description, this research reviews the use of social media on the North Sumatra Gubernatorial Election 2018 and its impacts on the emergence of functional civil society. The goal of this research is to highlight the role of information disseminated through social media and its impact on the emergence of functional civil society in North Sumatra Gubernatorial Election 2018.

\section{Theoretical Framework}

In relation to the state, civil society cannot be separated from the ongoing communication process. In essence, communication includes the elements of communicator as the messenger, the communicant as the recipient of the message, the message itself as delivered both in the form of symbols and images and sounds, channels as a messenger, and feedback or feedback expected to appear as an effect of the message delivered (Sahputra, 2016: 39).

Communication in the classical sense as stated by Harold D. Laswell in its formulas: Who (communicator) says what (message) in what channel (channel) to whom (communicant) with what effect (effect). Although this Lasswell model is more suitable for mass communication, it becomes the basis of many definitions of linear political communication, whose elements consist of political communicators, political messages, political channels or media, political targets or targets, and the influence or effect of political communication (Mulyana, 2014: 5).

In other words, political communication is communication that involves political messages and political actors, or is related to power, government and government policy (Wahid, 2018: 16). In political communication, what occurs openly, consisting of ideation processes, encoding, message delivery, decoding, and feedback, is an input from the norm formation process (Rosiana, 2015: 54).

In relation to political communication, the use of social media in the 2014 presidential election (Pilpres) was very influential in influencing political dynamics. Social media is such a powerful tool that even experts in any field cannot deny its capability whether it brings bad or good impact, as it is powerful enough to bring you down and cogent enough to bring you to the state of euphoria (Chinnasamya, 2018: 10). The increase in internet penetration rate in Indonesia cannot be separated from the influence of the popularity of social media among users, especially young people (Widhyharto, 2014: 142). Indonesia has made it to the top 4 Asian countries in terms of internet users. China takes the top spot with 731 million internet 
users, followed by India with 462.70 million internet users, Indonesia with 132 million internet users, Japan with 115.10 million internet users, and Bangladesh with 67 million internet users (Heryanto, 2018: 38).

Meanwhile, the research on civil society in East Asia has been attracting increasingly more attention from scholars of various fields that leads to more diverse and complex academic output (Didvalis, 2018: 13). Civil society is widely considered as a crucial element in contemporary society. Academic and policy makers have traditionally associated it with voluntary associations and organizations, assuming that associational life is an ideal intermediary between citizens and government (Van Dijck, 2017: 1).

Civil society in general is a much broader term and also includes informal, non-registered groups of power, such as social movements, civil initiatives and different ad hoc groups which can also be organised but which lack an organisational blueprint (Novak, 2017: 128). The central tradition in social policy has tended to argue that state institutions play a strong role in securing social cohesion (Taylor, 2012: 368). Civil society is understood as a realm separate from the state, economy, and private sphere, in which associations of various sort are active and in the one way or the other serve democracy and/or foster process of democratization or at least pursue common interests if not common good (Wischerman, 2011: 388).

Meanwhile, Arvidson et al define a local civil society regime is hence based on local political expressions of visions and expectations concerning the roles of civil society organisations and concrete forms of cooperation that express such political orientations (Arvidson, 2018: 7). Hiariej and Törnquist call the term political citizenship, which in Indonesia began in the early 20th century, together with the birth of the modern independence movement (Hiariej and Stokke, 2018: 62). Some scholars are more likely to refer to the term civil society which is related to terms in Islam, as "civil madani". Civil madani in the sense of civil society is a society with a civilized social system based on divine and moral principles, which guarantees a balance between individual freedom and the stability of society. Civil madani has high awareness of plurality, respects sciences and upholds human rights (Harahap, 2015: 210).

In North Sumatra, civil society grows and develops in two fundamentally different groups. First, structural civil society, which is affiliated to the state. This form is usually institutionalized and receives financial assistance from local governments. Second, functional civil society is born and developed based on the momentum that occurs from the shared needs of various elements of society.

Among the meanings of civil society mentioned, there is a red thread between the meaning of civil society as a term with civil society as an idea. But to treat it more dynamically, civil society must be seen as a social movement that grows in the middle of society as a channel for political aspirations to offset the role of power. In the context of Islamic-based social movements, Muslims move because of consciousness, not because of material benefits, such as political power, class interests, or group interests (Kuntowijoyo, 2018: 1).

\section{Material and Methodology}

This study uses a descriptive qualitative approach. In general, descriptive qualitative researchers strive to make their discussion more likely to be qualitative than quantitative, by approaching the meaning and sharpness of logical analysis. In this study, the data obtained will be collected and manisfested in the form of a description or an overview of the atmosphere of the object as a whole.

The study is a field study conducted to get first-hand experience and collect primary data from several events related to the North Sumatra Gubernatorial Election 2018. Secondary data is all data collected to support primary data collected from books, journals, articles, and news from media.

\section{Result and Discussion}

\section{Civil Society in North Sumatera}

In the North Sumatra Gubernatorial Election, the Eramas pair which is a Muslim-Muslim religious pair is widely perceived to represent the interests and aspirations of Muslims. Edy Rahmayadi who is a three-star general of the Indonesian National Army (TNI) is former Commander of the Army's Strategic Reserve Command (Pangkostrad), while Ijeck who is a successful young entrepreneur is the son of influential figure in North Sumatra, H. Hanif Shah.

Meanwhile, Djarot Saiful Hidayat who is a cadre of the Indonesian Democratic Party of Struggle (PDIP) was the running mate of incumbent Jakarta Governor Basuka Tjahaya Purnama (Ahok) who sought re-election in 2017. Djarot Saiful Hidayat inherited the post of Jakarta governor from Ahok from June 15, 2017 to October 15, 2017 after the latter was convicted of religious blasphemy. Ahok became Jakarta governor, replacing Joko Widodo who was inaugurated as Indonesia's seventh president on 
October 2014. In addition, Djarot Saiful Hidayat is the only candidate who is not from North Sumatra, meaning that he was not born and grown up in North Sumatra. While Sihar Sitorus, a successful businessman in the plantation sector, is the son of "king of the land" DL Sitorus.

In the 2018 simultaneous regional head elections held in 171 regions consisting of 17 provinces, 39 municipalities and 115 districts across Indonesia, Sihar Sitorus whose assets reached Rp350 billion is the richest among candidates who conveyed wealth reports (LHKPN) to the Corruption Eradication Commission (KPK). This pair is a combination of Muslim (Djarot Saiful Hidayat) and non-Muslim (Sihar Sitorus) perceived as representing the interests and aspirations of non-Muslims in North Sumatra. This ideological division in the North Sumatra Gubernatorial Election led to a strengthening movement filled with Muslims who became the power of civil society. In this article the movement that describes the Muslim civil society, is the "Movement of the Congregation of the Congregation", "Congress of Muslims", "The Political Lecture Movement in the Mosque".

The dominant movement in the North Sumatera Gubernatorial Election 2018 was a functional civil society. The membership of the functional civil society is filled by people from various groups of Islamic structural civil society. In other words, the members of structural civil society move in theth name of themselves in the functional civil society born by the momentum. Members of the community organize themselves for the common good. Before the emergence of the momentum, the power of this civil society did not reveal itself. Members of this functional civil society group come from different backgrounds and are united by common interests to move together to achieve common goals. This movement in North Sumatra is characterized by several basic things.

First, it was influenced by national issues related to Ahok's leadership as Governor of DKI Jakarta, who was found guilty of blasphemy against Islam. This condition creates feelings of alienation among Jakarta residents and Muslims in general. The Ahok case developed nationally because it touched a sensitive area, namely the blasphemy of Islam. Indonesia is the largest Muslim country in the world and the third largest democratic country in the world (Sahputra, 2016: 2);

Second, it was inspired by the enthusiasm of 411 and 212 anti-Ahok rallies in Jakarta which showed the solidarity action of Muslims from various parts of Indonesia to take part in the rallies against the blasphemy case;

Third, membership of functional civil society is cross-organizational and is bound by shared aspirations and interests in the ongoing social-political situation;

Fourth, the pattern of the movement is shaped by raising funds from each of its members who voluntarily donates funds;

Fifth, the pattern of movement is shaped by following the rules, regulations and procedures in place, and prioritizing rational thoughts by developing dialogues;

Sixth, the pattern of communication comes in the form of interaction through social media massively, as a form of communication between group members. Islamic clicktivism (Islamic online activism) is used for an action that can be measured its success in terms of virtual (online) and real (offline) (Ahyar, 2019: 25-26).

\section{Congress of Muslims}

The Congress of the Islamic Community was held in Medan Hajj Dormitory and lasted for three days from 30 March 2018 to 1 April 2018. The congress brought together Muslims from various parts of North Sumatra. The event was promoted intensively through social media platforms such as Facebook, Instagram, Whatsapp group and others. The information spread quickly and attracted enthusiasm from the community. This way social media creates an artificial atmosphere of polarization (Fadillah, 2019: 6). As a result, people from different backgrounds of Islamic community organizations took part in the event.

Among the representatives of Islamic community organizations present at the opening ceremony of the congress were from $\mathrm{Al}$ Washliyah, Muhammadiyah, Nadhlatul Ulama (NU), Al Ittihadiyah, Persatuan Islam (Persis), Matlaul Anwar, Front Pembela Islami (FPI), Forum Umat Islam (FUI), Hidayatullah, Ikatan Cendikiawan Muslim Indonesian (ICMI), Kaumi, Ikatan Da'i Indonesian (Ikadi), Mejelis Mujahidin Indonesian (MMI), Badan Koordinasi Pemuda \& Remaja Masjid Indonesian (BKPRMI), Gerakan Nasional Pengawal Fatwa Majelis Ulama Indonesian (GNPF MUI), Korps Alumni Himpunan Mahasiswa Islam (Kahmi), Gerakan Pemuda Islam Indonesia (GPII), Dewan Dakwah Islamiyah (DDI), Jaringan Pemuda Dan Remaja Masjid Indonesia (JPRMI), Pelajar Islam Indonesian (PII), Jam'iyah Batak Muslim (JBM), Perkumpulan Penguasaha Muslim Indonesian (PPMI), Persaudaraan Muslim Indonesian (Permusi), and other North Sumatera Muslim Community Organizations. 
The event was initiated to raise the national issue about the pressure of power in local leadership in North Sumatra. The Djarot-Sihar pair is considered a representation of the interests of power, besides being supported by the ruling party and its coalition (PDI Perjuangan and PPP). The activity which was initiated locally to take the momentum of the North Sumatra Gubernatorial Election featured a number of local and national figures, including Prof. Dr. Amien Rais, Prof. Dr. Yusril Ihza Mahendra, Bachtiar Chamsyah, Maj. Gen. (Ret.) Kivlan Zein, Drs Arso (Deputy Chairman of North Sumatra Chapter of the Indonesian Council of Ulemas/MUI), and Dr. Ir. Masri Sitanggang (Islamic Movement Activist who is the chairman of the event's organizing committee).

The event received very extraordinary responses and even greater responses than the organizing committee expected earlier. Hundreds of congressional participants came from 37 Islamic community organizations in North Sumatra. The participants stayed for three days following a series of sessions featuring speakers from national and local leaders. The Congress of Muslims in Medan resulted in the North Sumatra Islamic Charter covering:

First, the field of ukhuwah, which will, among other things, form a secretariat body along with Islamic Organizations to socialize the outcome of the congress held at the Hajj Dormitory on 30 March-1 April 2018;

Second, strengthening the political role of Muslims and reminding Muslims that they must constitutionally seize the power of the political superstructure in each state institution both in the executive and legislative institutions;

Third, Muslim socio-economic reinforcement, which will, among other things, encourage all Islamic mass organizations and Muslim entrepreneurs to create Islamic business entities (minimarkets, home industries and so on);

Fourth, strengthening the role of Islamic women. The leaders of Islamic women's organizations in North Sumatra, called on fathers and mothers (relatives) to increase their role in educating and assisting family members to avoid the dangers of narcotics, pornography, LGBT and promiscuity.

\section{The Fajr Movement Congregation}

The Fajr Movement in Congregation is a movement for Fajr prayer in congregation at the mosque. This confirms the distance between the community and the national government considered to support the Djoss pair. Of course, civil society is often perceived as the link between the government and the citizens (Novak, 2017: 140). This movement is a call for Muslims to enliven the mosque when Shubuh performs the Fajr prayer in congregation. This movement has been heard since a few years ago. An Omar Khalid @ pejuangsubuh27 social media account on Twitter has emerged since June 2010 and now has 3,742 followers and 341 following.

Furthermore, specifically the @PejuangSubuh account that has emerged since August 2012, was initiated by three people, namely Arisakti Prihatwono Hadi E. Halim, and Imam Rivani who struggled to enliven Fajr prayer in congregation as one of the pillars of Islamic revival. They aspire to the Fajr prayer congregation like Friday prayers. As of September 21, 018 the account had $223.8 \mathrm{~K}$ followers and 341 following. Since then, on the same social media platform several similar accounts have emerged and showed this movement has spread to various cities in Indonesia.

PejuangSubuhku@PejuangSubuhku (since November 2012, it has 1,652 followers and 1,934 following); PejuangSubuh Medan @PejuangSbhMedan (since 2013, it has 1,414 followers and 84 following); @PejuangSubuhBdg (since 2013 it has 4,445 followers and 167 following); $\quad$ \#YangMudaYangBAPER (PejuangSubuh Tangerang) @PejuangSubuhTNG (since 2013 it has 1,843 followers and 135 following); PejuangSubuhSumbar @Pejuangsubuhbkt (since 2013 it has 5,091 followers and 333 following); \#PS Surabaya @PejuangSubuhBGR (since 2013 it has 1,235 followers and 94 following); PejuangSubuh Depok @PejuangSubuhDPK (since 2014 it has 1,000 followers and 80 following); PejuangSubuh Banjarmasin@PejuangSubuhBJM (since 2013 it has 782 followers and 83 following); PejuangSubuh BOGOR @PejuangSubuhBGR (since 2013 it has 764 followers and 67 following).

\section{Speech at the Mosque}

Ahead of the voting day in the North Sumatra Gubernatorial Election on June 27, 2018, lectures by Muslim clerics were dominated by political material in terms of choosing leaders in Islam. The verses discussed in the present context of the Pilkada 2018 involve verses about choosing leaders in Islam, more specifically related to the prohibition of leading infidel leaders namely Surah Ali Imran verses 28, 118, 149, and 150; Surah An Nisa 'verses 138, 139, 141, 144; Surah Al Maidah verses 51, 57, 80, 81; Surah At Taubah verse 16, 23. Surah al Qasas verse 86; Surah Al Mujahad verse 14, 15; Surah Al Mumtahanah verses 1 and 13. 
The ustadz who lectured were generally driven by the obligation to preach to convey Islamic teachings to worshipers. Many of them are not bound by any campaign team. The ustadz who generally uncoordinated discussed the theme of choosing leaders in Islam which is was a hot theme. Massive activities of religious lectures at the mosque ahead of the North Sumatra Gubernatorial Election prompted the Minister of Religious Affairs of the Republic of Indonesia Lukman Hakim Saifuddin to issue a statement banning religious teachers and scholars from delivering lectures on practical politics in places of worship.

Lectures at mosques to elect MuslimMuslim leaders were also responded to by the General Election Supervisory Agency (Bawaslu) by issuing a circular. The circular Number B1601/K.Bawaslu-Prov.SU/PM.00.01/05/2018 concerns Submission of Agreements Reached at Coordination Meetings. The circular spread by hundreds of netizens in various social media platforms especially Facebook and Whatsapp Group.

In this case, social media are central to 'underground' election campaigns, promoting discourse to encourage citizens to fall into enclaves of identity politics (Fadillah, 2019: 7). One of the points in the circular, namely in number 4 letters a, $\mathrm{b}$ and $\mathrm{c}$, is provision banning candidate pairs, campaign teams, political parties and volunteers from conducting religious activities such as congratulating fasting and giving donations during the holy month of Ramadhan. The circular which circulated on social media on a chain basis caused repulsive reaction from Muslims. This issue became a topic of heated discussion among worshipers at mosque and in various meeting places. It even became lecture material at several mosques.

The circular was later revised by Bawaslu by issuing Circular Number B-1805/K.BawasluProv.SU/PM.00.01/05/2018 concerning Submission of Agreement on Results of the Coordination Meeting. Among the revised points are provisions in number 4 letter a stipulating that candidate pairs and campaign teams are banned from expressing Ramadhan greeting; during fasting, during sahur (predawn meal), breaking the fast, and during nuzulul quran (the revelation of the Quran), as well as Eid al-Fitr greeting in the form of advertisements on television, radio, print and electronic media. Under point $b$, candidate pairs are also prohibited to distribute imsakiyah time table, books of guidance on Ramadhan worship carrying the pictures of candidate pairs, serial numbers and or vision missions in places of worship.
Letter $\mathrm{c}$ of the circular contains a ban on delivering lectures or lecture about solicitation to choose or campaign for candidate pairs in places of worship. In letter $\mathrm{d}$, the candidate pair and the campaign team are banned from distributing alms including infaq, sadaqoh, holiday allowances, Eid gifts aimed at campaigning for the candidate pairs. In point e, Bawaslu warns of potential money politics or campaigns and said zakat, infaq and sadaqoh can be channeled through official institutions or amil zakat bodies. The Chairperson of North Sumatra Bawaslu Syafridah Rachmawati Rasahan argued that the circular circulating on social media was unrevised circular and Bawaslu has never circulated it because it is still subject to revision.

\section{Conclusion}

North Sumatra civil society is a complex symptom. One of the important factors is the occurrence of ideological division between Muslim-Muslim and Muslim-non-Muslim candidates in 2018. The Djoss Sihar pair is considered a representation of the interests of power, besides being supported by the ruling party and its coalition. Meanwhile, the Eramas pair is considered a representative of the Muslims in North Sumatra.

The leadership experience of Ahok as the Governor of DKI Jakarta who was later found guilty of blasphemy against Islam become a collective memory that drives the collective actions of Muslims. Muslims on the one hand not only support and favor Muslim-Muslim pair but also move consciously to campaign for MuslimMuslim pair.

Social media is an information media serving as s a means of mutual movement of exchanging information considered the fastest and most massive that forms a pattern of new social movements namely functional civil society. This movement is triggered by structural tensions at a level that is more than the individual level but occurs between the conflicting social actors. The emergence of resistance resulting from a gap between value expectation and value capability sparked dissatisfaction in the Muslim community. Functional civil society in the North Sumatra Gubernatorial Election 2018 as a movement shows its effectiveness for short-term goals to win the candidate pair.

\section{References}

Abbas, J., Aman, J., Nurunnabi, M., \& Bano, S. (2019). The impact of social media on learning behavior for sustainable education: Evidence of students from selected 
universities in Pakistan. Sustainability (Switzerland), 11(6), 1-23.

Ahyar, M. (2019). Aksi Bela Islam: islamic clicktivism and the new authority of religious propaganda in the millennial age in Indonesia. Indonesian Journal of Islam and Muslim Societies, 9(1), 1-29.

Akram, W., \& Kumar, R. (2017). A Study on Positive and Negative Effects of Social Media on Society. International Journal of Computer Sciences and Engineering, 5(10), 351-354.

Arvidson, M., Johansson, H., Johansson, S., \& Nordfeldt, M. (2018). Local civil society regimes: Liberal, corporatist and social democratic civil society regimes in Swedish metropolitan cities. Voluntary Sector Review, 9(1), 3-20.

Çela, E. (2015). Social Media as a New Form of Public Sphere. European Journal of Social Sciences Education and Research, 4(1), 195. https://doi.org/10.26417/ejser.v4i1.p195200

Chinnasamy, S., \& Abdul Manaf, N. (2018). Social media as political hatred mode in Malaysia's 2018 General Election. SHS Web of Conferences, 53, 02005. https://doi.org/10.1051/shsconf/2018530200 5

Coelho, P. M. F., Correia, P. A. P., \& Medina, I. G. (2017). Social media: A new way of public and political communication in digital media. International Journal of Interactive Mobile Technologies, 11(6), 150-157. https://doi.org/10.3991/ijim.v11i6.6876

Crosby, A. (2018). Review of Schneider's Policing and Social Media: Social Control in an Era of New Media. In Book Review, 16(1), 115117.

Didvalis, L. (Ed.). (2018). Civil Society in East Asian Countries; Contributions to Democracy, Peace And Sustainable Development. In Civil Society in East Asian Countries; Contributions to Democracy, Peace And Sustainable Development. Kaunas: Vytautas Magnus University. https://doi.org/https://dx.doi.org/10.7220/97 8-6094673252 (c)

Chukwuere, J. E., \& Chukwuere, P. C. (2017). The Impact of Social Media On Social Lifestyle: A Case Study Of University Female Students. Gender \& Behaviour, 9928-9940

Fadillah, D., Lin, L. Z., \& Hao, D. (2019). Social Media and General Election in Malaysia 2018 and Indonesia 2019. Jurnal Komunikasi Ikatan Sarjana Komunikasi Indonesia, 04(01), 1-8.
Fardouly, J., Magson, N. R., Johnco, C. J., Oar, E. L., \& Rapee, R. M. (2018). Parental Control of the Time Preadolescents Spend on Social Media: Links with Preadolescents' Social Media Appearance Comparisons and Mental Health. Journal of Youth and Adolescence, 47(7), 1456-1468. https://doi.org/10.1007/s10964-018-0870-1

Firdausi, I.A., Sururi, A. (2019). Kegagalan Komunikasi Politik Dinasti dalam Pemilukada Kota Serang 2018. Warta Ikatan Sarjana Komunikasi Indonesia. 2(1): 54-60.

Harahap, S. (2015). Islam \& Modernitas: Dari Teori Modernisasi Hingga Penegakkan Kesalehan Modern. Jakarta: Prenadamedia Group. Retrieved from http://repository.uinsu.ac.id/id/eprint/617

Heryanto, G. G. (2018). Media Komunikasi Politik: Relasi Kuasa Media di Panggung Politik. Yogyakarta: IRCiSoD.

Hiariej, E., \& Stokke, K. (2018). Politik Kewargaan di Indonesia. Jakarta: Pustaka Obor Indonesia.

Jati, W. R. (2016). Cyberspace, Internet, Dan Ruang Publik Baru: Aktivisme Online Politik Kelas Menengah Indonesia. Jurnal Pemikiran Sosiologi, 3(1), 25.

Johansson, A. C. (2016). Social Media and Politics in Indonesia. Stockholm School of Economics Asia Working Paper No. 42, (42), $1-44$.

Kuntowijoyo. (2018). Identitas Politik Umat Islam. Jakarta: IRCiSoD.

Lee, E. S., \& Jung, K. (2018). Dynamics of social economy self-organized on social media: following social entrepreneur forum and social economy network on Facebook. Quality and Quantity, 52(2), 635-651. https://doi.org/10.1007/s11135-017-0663-8

Madueke, O., Nwosu, C., Ogbonnaya, C., \& Anumadu, A. (2017). The Role of Social Media in Enhancing Political Participation in Nigeria. Journal of Arts and Management, 2(3), 44-54.

Maryani, E. (2018). Developing Social Solidarity through Digital Media. Jurnal Komunikasi Ikatan Sarjana Komunikasi Indonesia, 3(1). https://doi.org/10.25008/jkiski.v3i1.144

Mulyana, D. (2014). Komunikasi Politik Politik Komunikasi (Membedah Visi dan Gaya Komunikasi Praktisi Politik). Bandung: Remaja Rosdakarya.

Murwani, E. (2018). The Impression Management Strategy of the Candidates of Governor-Vice Governor of DKI Jakarta on Social Media. Jurnal Komunikasi Ikatan Sarjana 
Komunikasi Indonesia, 3(2). https://doi.org/10.25008/jkiski.v3i2.219

Novak, M. (2017). Who is Organised Civil Society Accountable to? The Population of Civil Society Organisations In Slovenia. TEORIJA IN PRAKSA, 54, 127-144.

Pangestuti, S., Herutomo, C., Istiyanto, S.B., (2018). Pembelajaran Politik untuk Pemilih Pemula Melalui Media Sosial di Purwokerto, Jawa Tengah. Warta Ikatan Sarjana Komunikasi Indonesia. 1(2), 1-6.

Pulido, C. M., Redondo-Sama, G., Sordé-Martí, T., \& Flecha, R. (2018). Social impact in social media: A new method to evaluate the social impact of research. PLOS ONE, 13(8), 1-20. https://doi.org/10.1371/journal.pone.020311 7

Putri, R. E. (2015). Komunikasi Politik (Model Komunikasi Politik Antar Fraksi dalam Pembentukan Norma UU Pilkada Secara Demokratis). Jurisprudence, 5(1), 50-63.

Ritonga, R., \& Syahputra, I. (2019). Citizen Journalism and Public Participation in the Era of New Media in Indonesia: From Street to Tweet. Media and Communication, 7(3), 79. https://doi.org/10.17645/mac.v7i3.2094

Sahputra, D. (2016). Komunikasi Politik Partai Politik Islam. Yogyakarta: Orbit.

Sahputra, D. (2019). Politik Dan Media Massa dalam Dinamikanya Dengan Pendapat Umum, Komunikasi Massa, Komunikasi Politik Dan Media Massa. Jakarta: PWI Pusat.

Saraswati, M. S. (2018). Social Media and the Political Campaign Industry in Indonesia. Jurnal Komunikasi Ikatan Sarjana Komunikasi Indonesia, 3(1). https://doi.org/10.25008/jkiski.v3i1.124

Suardi. (2016). Antara media sosial dalam komunikasi politik. Jurnal RISALAH, 27(2), 82-86.

Susanto, E. H. (2017). Media Sosial Sebagai Pendukung Jaringan Komunikasi Politik. Jurnal ASPIKOM, 3(3), 379. https://doi.org/10.24329/aspikom.v3i3.123

Tariq, W., Mehboob, M., \& Khan, M. A. (2012). The Impact of Social Media and Social Networks on Education and Students of Pakistan. International Journal of Computer Science Issues, 9(4), 407-411.

Taylor-Gooby, P. (2012). The civil society route to social cohesion. International Journal of Sociology and Social Policy, 32(7/8), 368385.

https://doi.org/10.1108/0144333121124900 $\underline{2}$
Thang, S. M., Noor, N. M., Taha, A. M., Ng, L. S., \& Aziz, N. B. A. (2016). Effects of Social Networking on Malaysian Secondary School Students: Attitudes, Behaviours and Awareness of Risks. Pertanika Journal of Social Sciences and Humanities, 24(S), 157-168.

Umar, A. R. M., Darmawan, A. B., Sufa, F. S., \& Ndadari, G. L. (2014). Media Sosial dan Revolusi Politik: Memahami Kembali Fenomena "Arab Spring" dalam Perspektif Ruang Publik Transnasional. Jurnal Ilmu Sosial dan Ilmu Politik, 18(2), 114. https://doi.org/10.22146/jsp.13130

van Dijck, M. F., de Munck, B., \& Terpstra, N. (2017). Relocating civil society: Theories and practices of civil society between late medieval and modern society. Social Science History, 4l(1), 1-17. https://doi.org/10.1017/ssh.2016.35

Wahid, U. (2016). Komunikasi Politik: Teori, Konsep, dan Aplikasi Pada Era Media Baru. Bandung: Simbiosa Rekatama Media.

Widhyharto, D. S. (2014). Kebangkitan Kaum Muda dan Media Baru. Jurnal Studi Pemuda, 3(2), 141-146.

Williams, B. D., Valero, J. N., \& Kim, K. (2018). Social media, trust, and disaster: Does trust in public and nonprofit organizations explain social media use during a disaster? Quality and Quantity, 52(2), 537-550. https://doi.org/10.1007/s11135-017-0594-4

Wischermann, J. (2011). Governance and Civil Society Action in Vietnam: Changing the Rules from Within-Potentials and Limits. Asian Politics and Policy, 3(3), 383-411. https://doi.org/10.1111/j.19430787.2011.01277.x 